\title{
Formalizing Informal Settlements to Empower Residents Against COVID-19 and Other Disasters
}

\author{
Chryssy Potsiou
}

With the COVID-19 it became obvious that the significant social and economic benefits of the urbanization and globalization era may be accompanied by a globalized threat and risk. This deadly virus struck fast and hard and with little warning and all countries, even the most developed, have proved to be unprepared. Governments have urgently explored short- and long-term actions on how to sustain a resilient economic and social activity while keeping their people safe, but also on defining policies that would help them to deal with the post-COVID-19 challenges. In this respect, the 2019 UNECE publication on Guidelines for Formalization of Informal Constructions may be useful to facilitate a global planning process to support a large number of states that face the challenge of construction informality in developing fit-for-purpose policies while preparing for a post-COVID era. According to UNECE, benefits from formalizing informal constructions could contribute to economic recovery by integration into land markets with clear ownership titles and registration. Security of tenure and rights to ownership of land and property provide access to credit; environmental planning, construction, and utility-provision improvements can be initiated to a standard by which people can live in adequate and healthy homes to the benefit of all. This chapter provides an insight of the above issues and draws the attention to the benefits of a clear and inclusive strategy and of a fit-for-purpose formalization framework.

\subsection{Introduction}

The COVID-19 pandemic is threatening cities and settlements all over the world, endangering not only public health but also the economy and the structure of society, forcing us apart as we try to slow the spread of the virus. However, we - as individuals - are still finding ways to help each other, inspiring and showing appreciation for those helping our communities, keeping in touch with family members wherever they may be, and most importantly, helping the poorest and most vulnerable, those least able to respond.

But how can we, as experts, do more? How can we support governments to do the same at a larger scale successfully? More specifically, how can surveyors, as geospatial and land professionals, provide appropriate tools that will support governments in their efforts to be more efficient in empowering those most vulnerable, increasing recognition of disease and pandemics? "Who" and more importantly "where" are the most vulnerable, those exposed most to the pandemic?

This discussion will address the following questions:

1. how can geospatial experts and land surveyors provide the technically driven policy tools to 
support governments to identify and empower those most vulnerable and those exposed most to the pandemic?

2. why the measures taken by governments to empower people against the pandemic are also related to the good management of land and therefore need to be more "localized", evidence-based, and fit-for-purpose? and

3. how governments may develop "fit-for-purpose" formalization projects to empower residents in informal settlements for the benefit of all?

\subsection{The Need for Geospatial Data and Tools to Improve Decision-making}

It is said that flooding and other natural disasters are more or less "localized" and authorities, with the support of geospatial experts, know that they may turn "there" to help, while the current COVID-19 disaster is or may exist "everywhere", which complicates recovery actions, and that affects everyone with a priority for the elderly, those with chronic health problems, and those who have difficulty protecting themselves.

As with any natural disaster, the way countries and communities prepare for a damaging event makes the difference for a successful, long-term resilience and recovery. Decision-making for such preparation must be evidence-based; therefore, availability of reliable and affordable geospatial data in a timely manner is crucial. This is at the center of surveyors' professional skills, interests and activities. There are already several modern, low-cost but still reliable tools and methods that may be used for acquiring the needed geo-referenced information including information derived from social media and crowdsourcing [1] and several applications for contact tracing, that may help in providing sound decision-making for applying more "localized" rather than "general" measures, and for providing humanitarian support when dealing with such disasters [2].

Unfortunately, this virus struck fast and hard and without warning and all countries, even the most developed, were unprepared. It has been a common and long-established public confidence that medicine has improved significantly and that humanity has managed to overcome problems caused by pandemics that once killed large numbers of people, and which have thus influenced the history and the future of many cities [3]. Since that development in the history of medicine, and for several years since, research in infectious diseases has lost its institutional urgency.

As a result, rapid and dense urbanization became more and more a global trend for several decades and has been considered as the tool to deal with poverty which would lead us to economic growth for all. A globalized economy has developed and the world has been on a constant move to urbanization. Surveyors have always been in the front line aiming to provide the most appropriate policies, methods and tools to provide the required geo-referenced data to support the management of the emerging mega cities [4]. A global action plan on how to deal with deadly pandemics is still missing; there is a significant lack of awareness among populations and unfortunately a dangerous lack of coordination among governments in terms of disaster-response measures. The result is a dangerous confusion. Coronavirus was a test, and the world's supposedly most advanced nations have all too visibly failed [5].

Governments are now urgently exploring short- and long-term actions on how to sustain a resilient economic and social activity while keeping their people safe, but also on how to deal with post-COVID-19 challenges; it is anticipated that the pandemic will have a continuing multidimensional impact. Such actions and policies should be based on reliable geospatial data.

The situation becomes worse in unplanned and/or dense informal settlements and slums that often exist on the outskirts of many large urban areas, but which also provide unskilled service support to the nearby urban economies. Residents in informal settlements usually are not registered, they may even lack citizenship, identity cards and addresses but also health care, basic services like clean water and sewage disposal, etc. It has become obvious that unfortunately COVID-19 
has a higher, "localized" concentration among informal settlement residents where people are not prepared, basic infrastructures are poor, and where there is a significant lack of reliable geo-referenced data. (A strategy for containment of the virus is "contact tracing" in which an attempt is made to track the progress of the disease from population center to population center, requiring an efficient geo-referenced measuring and monitoring system.)

The World Bank reports that the COVID-19 pandemic has plunged the global economy into its deepest recession since World War II. It estimates that this particular disaster will create the worst economic contraction in decades, with numerous job losses and the creation of 60-100 million of "new poor", mainly those self-employed, many informally, which will soon join those most vulnerable - those poor living in the informal settlements; and foresees that the COVID-19 pandemic is a once-in-a-century crisis that presents extraordinary challenges to policymakers around the world $[6]$.

According to the IMF the economic impact of this crisis will be like no other; GDP is expected to fall by some $6-7 \%$ this year in the advanced economies, and it will not return to its pre-virus peak until at least 2022. Given the uncertainty around how long the pandemic will last, it may be far worse. Entire sectors of the economy are at risk. Millions of people have already lost their source of income. The International Labor Organization (ILO), at its press release of 29 April 2020 , estimated that 1.6 billion workers in the formal or informal economy, amounting to nearly half the global workforce, are at risk of losing their livelihoods. This is due to the lockdown measures and/or because these people are occupied in the hardest-hit sectors, such as wholesale and retail, manufacturing, accommodation and food services, or the real estate sector [7]. What is even worse is the fact that usually these people have no access to credit.

It is "there", at such settlements, that governments should turn their attention to help and provide the means for improvements and resilience.

These people are least able to protect themselves. "As the pandemic and the jobs crisis evolve, the need to protect the most vulnerable becomes even more urgent" said ILO Director-General Guy Ryder. "For millions of workers, no income means no food, no security and no future. Millions of businesses around the world are barely breathing. They have no savings or access to credit. These are the real faces of the world of work. If we don't help them now, these enterprises will simply perish" [8].

The informal economy includes informal construction - self-made, usually substandard, houses - along with the informal labor force and illegal businesses. Informally, self-made cities/settlements in general [9], with informal, unregistered property rights, lacking property titles and/or planning, construction and operational permits, have no access to credit. Informal rights and informal construction constitute a wide-spread challenge threatening sustainability and although "... access to basic services, ownership and control over land and other forms of property, inheritance, natural resources,..." is included at SDG1 (target 1.4) of the UN Sustainable development Agenda 2030 [10], so far few countries have reported on real progress in this field in the five years of implementation period, as emphasized at the recent webinar "Five years into the SDGs - Are we on track to deliver the land targets?" [11], with the World Bank predicting that "the global community's significant progress on poverty reduction in recent decades will likely be partly reversed and that it will also be more difficult to achieve broader development goals by the end of this decade" [6].

UNECE and FIG have long worked in this field and land surveyors have built experience in developing fit-for-purpose technical, administrative, legal and policy tools both for the registration of informal tenure rights as well as for the formalization of informal constructions. There is an urgent need that governments will now integrate such tools to improve the preparedness measures for the pandemic. 


\subsection{Measures Taken by Governments to Manage the Pandemic}

A common, immediate response of many governments during the disease outbreak was to request their citizens to "stay at home", "work from home", "keep social distance", "follow basic hygienic measures" and "wash hands with soap and clean water frequently".

These measures have been successfully adopted by many citizens, but unfortunately they seem unrealistic for some people as well as for most residents of informal settlements; residents of informal settlements simply cannot cope with such requirements. A number of issues need to be taken into consideration:

1. Housing conditions in informal settlements are usually substandard, lacking access to basic hygienic services such as drinking water and/or sanitation, waste collection and access to basic health care, while density in such areas does not allow residents to maintain the necessary social distancing.

2. These people cannot earn their daily income while social distancing; they can rarely work from home. Occupants of such informal constructions are usually unregistered workers, or are occupied on a temporary basis, in a myriad of businesses, small or medium enterprises, usually informal; these people, every morning, afternoon or night must leave their homes to go out, to ensure that they will bring back enough food for family members while keeping the economy running for the rest of the urban citizenry, experiencing emotional, physical and mental stress every day.

3. A large percentage of such informal labor force is occupied in transportation, construction, and agriculture/food production, supplying farmers and handling food from "farm to fork;" in many cases this is crucial for maintaining sustainability in the supply chain.

4. A significant number of residents of informal settlements, either rural or urban, are women who are harshly impacted by land tenure insecurity due to discriminatory laws and a lingering social bias. The COVID-19 virus threatens to exacerbate a situation of social gender inequality.

As COVID-19 continues to spread through society common measures are not being adopted by all governments and it becomes clear that strict measures that radically change everyday activities cannot easily be enforced and cannot easily control the disease. While restoring global health remains the uppermost priority, as mentioned above, it is apparent that the strict measures required have caused massive economic and social shock. The prolongation of a lockdown, physical distancing and other isolation measures used to eliminate transmission of the virus will lead the global economy into a recession. Unemployment, loss of income and the risk of more homelessness are the result.

Many countries are using additional "social safety net programs" to respond and protect families from the impact of economic shock. They provide, among other devices, loans with low interest, cash, in-kind transfers, social pensions, public works, and school feeding programs targeted to poor and vulnerable households. Some have enacted measures to secure housing tenure for tenants and occupants of camps and informal settlements in response to this crisis. Among those jurisdictions who have put in such measures, many have moved to enact moratoriums on evictions and utilities shut-offs, and some have put in measures to reduce rents or offer moratoriums to non-performing housing loans and foreclosures, or rental subsidies to the most vulnerable households.

However, the cost of such measures is significantly preventing their broad application. Most frequently beneficiaries of such measures are those registered, meaning those working and living in the formal sector; residents in informal settlements are once again likely to be left behind. But, we should acknowledge that allowing substandard conditions in some areas is not only a threat to those residents, but to the general population as well. Infected residents through their activity very soon will transfer the virus to the people they have job contacts within the city or other regions.

Moreover, the COVID-19 crisis is also anticipated to accelerate a disruption in the housing sector that started well before this crisis. The construction and real estate sector is an industry that tends to be vulnerable to economic cycles. External market factors, combined with fragmented 
and complex industry dynamics and an overall aversion to risk, already had made the provision of formal affordable housing adequate for all, a problematic process. This is expected to worsen due to the virus thus anticipating larger numbers of people seeking an alternative and affordable but informal housing solution.

Governments need to seriously consider new fit-for-purpose ways and tools to manage and administer land [12] as well as to formalize existing informal constructions in order to enable access to credit for those residents, to improve their living conditions and to enhance the needed hygienic and safety improvements in such constructions. It is more important than ever for all actors to see what the "next normal" will look like and make the bold, strategic decisions to create a better future for all by solving the persistent shortage of formal housing.

\subsection{How to Formalize Informal Construction in Order to Empower Residents against COVID-19}

Informal development is a social phenomenon in which people settle on land that may be owned by others or by the state, where they build dwellings usually sub-standard and temporary in nature. These settlements may have limited or no infrastructure. Informal development may even appear on legally owned land while its illegality is related to zoning, planning, or building regulations. An illegal building is one built without a construction permit, or in violation of a legally issued permit or against the verified basic legal land plan. In many cases illegal construction in the European transition countries is of a good, permanent type, and can be characterized as self-made "affordable housing" rather than as "slums", although they may not meet all construction stability, safety and environmental standards. Illegal buildings are usually out of the economic circle, not registered, not taxed and unable to be transferred or mortgaged. These constructions represent "dead capital" of a country's economy; the problem is well known in the UNECE region. Unregistered, informal constructions cannot be used as collateral to provide access to vital credit for their occupants (and do not appear on the public record for land taxation purposes). A great support that governments may provide to residents in informal settlements may be to enable formalization of informal constructions, where possible, thereby integrating them into the land administration systems and into property markets. As a result access to credit will be enabled and people may use this funding to improve their living situations with improved protection against the disease. But which is the most appropriate method of formalization?

The UNECE and the Working Party on Land Administration (WPLA) initiated joint research together with the International Federation of Surveyors (FIG) in 2007 on the topic of informal development in the region. The main objective of this research was to identify the size of the problem in the UNECE region, the causes, the types of informal constructions and to assess the formalization methods used by governments in eight countries [13-20], and to identify good practices.

The research identified that more than 50 million people in 15 member States of the United Nation Economic Commission for Europe (UNECE) live in informal settlements. The causes of current informal settlements include major political changes in law and regulation coupled with rapid urbanization, and often uncontrolled, massive internal migration. Conflict, marginalization, cumbersome authorization processes for home improvements and modernization, and corruption resulted. But the list of causes is more complex, including the absence of policies by the states and their failure to adopt pro-growth planning as well as affordable housing policies; weaknesses of the private sector; the lack of knowledge and political will to develop land policies to facilitate recognition of existing tenure and private property rights to aid the transition from centrally planned to market economies; and the failure or reluctance of state agencies to implement measures to support economic reforms to facilitate the digital economy and the UN Sustainable Development Agenda 2030.

The types of informal constructions in the region include a large range of buildings from small single family houses to multi-story apartment buildings, shops, hotels and public buildings. They may lack ownership titles and/or building and planning permits, or they may have been built in 
excess of legally issued permits. Formalization policies adopted from the various governments to address the problem often lack a clear fit-for-purpose strategy and in many countries formalization is a long bureaucratic and expensive procedure; or may start with the best of intentions but become bogged down due to administrative bottlenecks or change of government. Governments often understand the problem but do not fully recognize the extent of its impacts. Therefore, it was necessary to develop guidelines which would explain why a country would choose to go beyond the established scientific/engineering/planning practice in order to successfully deal with property market challenges, funding challenges, structural stability challenges, environmental challenges and difficult ethical challenges as well as the many hostile reactions to a formalization project by otherwise law-abiding citizens [21].

This long research resulted in the compilation of guidelines for a fit-for-purpose formalization framework in support of those countries seeking a quick and sustainable formalization solution in an affordable, reliable, inclusive and timely manner to improve residents' health, living and working conditions and to meet the SDGs by 2030. The guidelines focus mainly on providing instructions on how to organize the formalization project, but it also provides information about the necessary preparatory work (e.g., how to identify the problem's magnitude and how to develop a strategy to achieve a general political acceptance), as well as information about important post-formalization factors.

It is important that the formalization process, as well as its strategy, will clarify and quantify the anticipated economic, environmental and social benefits and ensure that everyone, not just the residents of informal settlements, sees benefits from formalization. The process should be based on three main pillars: (a) to facilitate increased tenure security, (b) to recognize the right to adequate housing for all, and (c) to provide access to credit for the residents in informal settlements. Guidelines are aligned with the UN SDGs, especially SDG 1, target 1.4, SDG 11, SDG 5, the FAO Voluntary Guidelines on the Responsible Governance of Tenure of Land, Fisheries and Forests (VGGT) and the New Urban Agenda.

These guidelines, published in 2019 by the United Nations, are written mainly for countries within the UNECE region where informal constructions are of fairly good quality (not slums) and therefore could be considered as a commodity, which may provide access to credit and funds to be used by the residents either for construction improvements or for other general improvements of the neighborhoods e.g., to enable disaster recovery, education and health services, or to develop businesses. The guidelines are meant to be used by all sectors and stakeholders involved, such as politicians, government members, state agencies, all involved professionals, as well as academics, NGOs and banks.

It is anticipated that the guidelines will be applicable in other regions, too. In the "new normal" era titling provision and registration should be quick and of low cost and should be independent from other types of informalities (lack of planning and/or construction permits). Post-formalization or parallel planning, environmental considerations, construction improvements as well as service-provision should be enabled not only for social and environmental reasons, but also to make these properties more economically viable and attractive in order to become part of the broader legal real estate market and to enable access to credit. Otherwise, it is hard to realize equity in a house that cannot be sold or is without interest in the real estate market.

However, there is no "one size fits all" general rule for improvement provision; such improvements can be initiated and funded by the residents in partnership with national and local authorities, as well as the private sector. Tools to be used for urban regeneration may include consolidation of parcels and land readjustment. Such land reforms require a broad public awareness and acceptance, as well as trust and willingness of residents to participate voluntarily to secure ownership rights to their homes. In general, the success of such a project is based on the voluntary participation of residents. Eliminating the informality phenomenon in future requires, apart from title provision and property registration, comprehensive land policies and reforms that may include pro-growth planning, flexible permitting/inspection processes for development, property valuation, policies for creating job opportunities, fair taxation and affordability. Other issues relevant to the establishment of real estate markets should be also addressed, which include the existence of funding mechanisms, professional education, professional ethics and an effective role for the private sector $[22]$. 
When dealing with formalization one should remember that demand in real estate markets is defined not only by consumer need, but also by consumer desire and when neither the state nor the private sector provide, legally, the supply of appropriate real estate types and quantities to satisfy the current demand, people may build informally with a result that is inherently risky.

Also, one should remember that security of tenure is a social issue and a human right; security of ownership rights and of titles may also be a social issue as it is fundamental to the well-being of residents. But security of tenure alone cannot facilitate access to credit, while security of ownership rights may. A country without an inclusive formal system for registering property rights limits its own economic development and prevents its citizens from realizing their full potential.

The formalization of informal constructions, among several other improvements, will enable:

1. reduction of evictions by the establishment of updated cadastral systems and increased security of rights;

2. risk reduction thus enabling occupants' access to credit at affordable interest rates, as well as a significant tool for funding their housing and resistance to any natural and/or manmade disasters;

3. occupants to improve their housing and business conditions; improvement of planning of neighborhoods and construction stability; improvement to family health issues; children's education; security;

4. authorities to use this updated spatial data infrastructure for evidence-based decision-making for a series of issues, e.g., to enable digital transformation of society; to build reliable basic registers; to add other necessary information or improve various statistical records; to apply good and fair land and property policies; to monitor and improve important health and other SDG indicators, such as for environmental issues; to support agriculture and food production, education and employment, gender equality and transportation and to provide humanitarian support;

5. the transformation of dead capital locked up in informal constructions to become productive capital thus increasing a nation's GDP with faster economic recovery and poverty alleviation. Such assets as formalized constructions may provide collateral and increased revenue from land taxation to improve basic infrastructure and provide electricity and digital access to all people, which is basic for a restart of national economies especially in the poorest countries.

The UNECE Guidelines for formalization of informal constructions may be of particular interest to governments preparing for the post-COVID era. Benefits from a fit-for-purpose formalization of informal settlements could contribute to economic recovery by providing property titles, registering them in the cadastral systems and integrating them into the local economies.

Experts involved in the compilation of these Guidelines are currently working under the guidance of UNECE for identifying ways to monitor the implementation of the Guidelines in the region. More specifically, a follow up project is carried on with a purpose to review how well countries that face the challenge of informal development have progressed with their formalization projects and if there is a need for some revision of the process, what is actually the impact of Covid-19 in these regions, and what are the actions taken by governments during the Covid-19 period. Some seminars and lectures will be organized soon aiming to raise awareness about the importance of the Guidelines and their fast and inclusive implementation. It is highly recommended though that the experience gained from UNECE region will be shared in other regions, too, that are facing similar challenges.

\section{References}

[1] V. Cetl, C. Ioannidis, S. Dalyot, Y. Doytsher, Y. Felus, M. Haklay, H. Mueller, C. Potsiou, E. Rispoli, and D. Siriba. New Trends in Geospatial Information: The Land Surveyors Role in the Era of Crowdsourcing and VGI. International Federation of Surveyors (FIG): FIG Publication No. 73, 2019. 
[2] United Nations UN. Sendai Framework for Disaster Risk Reduction 2015-2030. URL https://www. preventionweb.net/files/43291_sendaiframeworkfordrren.pdf.

[3] C. Potsiou. Spatial Data Infrastructures in Support of Land Governance and Natural Disaster Prevention and Management - The FIG Com3 activity. In 2nd GIS National Congress in Turkey on "NSDI and working cooperatively for a liveable future”. FIG, 2009.

[4] Y. Doytsher, P. Kelly, R. Khouri, R. McLaren, H. Mueller, and C. Potsiou. Rapid urbanization and mega cities: the need for spatial information management. Denmark. International Federation of Surveyors (FIG): FIG Publication No. 73, 2010.

[5] J. Crabtree. How to manage a pandemic, 2020. URL https://ww.technologyreview.com/magazines/thecoronavirus-issue/. MIT technology review Magazine.

[6] The World Bank Group WB. Global Productivity: Trends, Drivers, and Policies, 2020. URL https://www. worldbank.org/en/research/publication/global-productivity.

[7] ILO. A policy framework for tackling the economic and social impact of the COVID-19 crisis, 2020. URL https://www.ilo.org/wcmsp5/groups/public/@dgreports/@dcomm/documents/briefingnote/wcms_ 745337.pdf. Press release.

[8] ILO. As job losses escalate, nearly half of global workforce at risk of losing livelihoods, 2020. URL https: //www.ilo.org/global/about-the-ilo/newsroom/news/WCMS_743036/lang--en/index.htm.

[9] S. Tsenkova, C. Potsiou, and A. Badyina. Self-made Cities. Search for Sustainable Solutions for the Informal Settlements in the United Nations Economic Commission for Europe Region, 2009.

[10] United Nations UN. UN transforming the world: the 2030 Agenda for Sustainable Development, . URL https://sustainabledevelopment.un.org/post2015/transformingourworld.

[11] Land Portal. Five years into the SDGs: are we on track to deliver the land targets? URL https://www. youtube. com/watch?v=uxYj09BVbjQ.

[12] S. Enemark, K. C. Bell, C. Lemmen, and R. McLaren. Fit-For-Purpose Land Administration. International Federation of Surveyors (FIG): FIG Publication No. 60, 2015.

[13] C. Potsiou. Informal Urban Development in Europe - Experiences from Albania and Greece. UN Habitat, 2010 .

[14] C. Potsiou and S. Basiouka. Security of ownership versus public benefit: A case study for land taking for infrastructure in Greece as an EU member state. Survey Review, 44(325):111-123, 2012.

[15] C. Potsiou and S. Basiouka. Policies for formalization of informal development: recent experience from southeastern Europe. Land Use Policy, 36(325):33-46, 2014.

[16] C. Potsiou and K. Dimitriadi. Tools for Legal Integration and Regeneration of Informal Development in Greece: A Research Study in the Municipality of Keratea. Surveying and Land Information Sciences (SaLIS), 68(2):103-118, 2008

[17] C. Potsiou, M. Theodorou, and E. Elikkos. Informal Development Due to Market Pressure-A Case Study on Cyprus and the Role of Land Administration. Nordic Journal of Surveying and Real Estate Research, 2009.

[18] C. Potsiou and K. Dimitriadi. Illegal Development in a State Controlled Economy in transition: the case of Montenegro. South-Eastern European Journal of Earth Observation and Geomatics, 3(1a):71-85, 2014.

[19] C. Potsiou. Formalizing the Informal: Challenges and Opportunities of Informal Settlements in South-East Europe. United Nations, 2015.

[20] C. Potsiou and C. Ioannidis. Informal settlements in Greece: The mystery of missing information and the difficulty of their integration into a legal framework. In Proceedings of 5th FIG Regional Conference for Africa, Accra, Ghana. FIG, 2006.

[21] C. Potsiou, S. Nystrom, R. Wouters, and A. Figueiredo. Guidelines for the formalization of informal constructions. UNECE, 2019.

[22] Estate Market Advisory Group UNECE. Policy Framework for Sustainable Real Estate Markets. United Nations, 2010 